\title{
PENGARUH KUALITAS PRODUK TERHADAP KEPUASAN KONSUMEN PADA CELDI KATERING (SURVEI PADA KONSUMEN CELDI KATERING)
}

\author{
Masharyono ${ }^{1}$ \\ Universitas Pendidikan Indonesia, Manajemen Bisnis FPEB: \\ masharyono@upi.edu \\ Cita Urwah Hasanah ${ }^{2}$ \\ Mahasiswa Universitas Pendidikan Indonesia, Manajemen Industri Katering \\ FPIPS: citauh@yahoo.co.id
}

\begin{abstract}
ABSTRAK
Perkembangan usah jasa boga di Indonesia cukup berkembang dengan pesat. Kondisi ini ditunjangn dengan pergeseran pola hidup yang menyukai kepraktisan termasuk dalam hal makanan. Terutama bagi orang yang sibuk bekerja tidak memiliki banyak waktu untuk mengolah dan menyiapkan makanan sendiri sehingga mereka mulai beralih dengan memanfaatkan jasa penyajian makan siap saji yang disebut juga pelayanan jasa boga. Salah satu usaha yang bergerak di bidang usaha jasa boga adalah Celdi Catering. Permasalahan yang dihadapi oleh Celdi Katering saat ini adalah terjadinya penurunan jumlah profit. Dugaan semua ini karena adanya ketidakpuasan dan ditemukanya beberapa keluhan terhadap kualitas produk yang diberikan oleh Celdi Katering. Oleh sebab itu tujuan dari penelitian ini adalah untuk mengetahui bagaimana pengaruh kualitas produk terhadap kepuasan konsumen pada Celdi Katering. Metode yang digunakan dalam penelitian ini adalah deskriftif dan verifikatif. Sedangkan pengumpulan data dengan cara menyebar kuesioner. Teknik analisis data dengan menggunakan regresi linear sederhana. Hasil penelitian menunjukkan bahwa kualitas produk memiliki pengaruh terhadap kepuasan konsumen. Saran dalam penelitian ini adalah perusahaan harus bisa meningkatkan setiap dimensi dari kualitas produk terutama untuk dimensi temperature (panas/suhu) dan texture/form/shape (susunan/bentuk/potongan).
\end{abstract}

Kata Kunci: Kepuasan Konsumen, Kualitas Produk

\section{EFFECT OF PRODUCT QUALITY ON CUSTOMER SATISFACTION IN CATERING CELDI (SURVEY ON CONSUMER CELDI CATERING)}

\begin{abstract}
Developments need catering services in Indonesia is growing rapidly. This condition is supported by shifting lifestyles, like the practicality of including
\end{abstract}


in terms of food. Especially for people who are busy at work does not have much time to process and prepare the food themselves so that they start switch by utilizing the services of fast food presentation called also catering services. Especially for people who are busy at work does not have much time to process and prepare the food themselves so that they start switch by utilizing the services of fast food presentation called also catering services. One of the business engaged in the catering business is Celdi Catering. The problem faced by Celdi catering today is the decreasing amount of profit. Alleged all of this because of the dissatisfaction and ditemukanya several complaints against the quality of the products supplied by Celdi catering. Therefore, the purpose of this research is to know how to influence product quality to customer satisfaction in Celdi Catering. The method used in this research is descriptive and verification. While the collection of data by spreading the questionnaire. Data analysis techniques by using simple linear regression. The results showed that the quality of the product has an influence on customer satisfaction. The suggestion in this research is the company should be able to improve each dimension of quality products mainly to the dimensions of temperature (heat /temperature) and texture/form/shape (composition/forms/piece).

\section{Keywords: customer satisfaction and product quality}

\section{PENDAHULUAN}

Industri Pariwisata saat ini memegang peranan penting dalam perekonomian Indonesia sebagai salah satu sumber penghasilan devisa maupun sebagai pencipta lapangan kerja dan kesempatan berwirausaha. Industri pariwisata adalah kumpulan usaha pariwisata yang saling terkait dalam menghasilkan barang dan atau jasa bagi pemenuhan kebutuhan wisatawan pada penyelenggaraan pariwisata. Salah satu usaha pariwisata yang menyediakan makan dan minum adalah usaha jasa boga.

Perkembangan usah jasa boga di Indonesia cukup berkembang dengan pesat. Dimana usaha ini yang dulunya dianggap sebagai home industry atau pun pekerjaan sambilan bagi ibu-ibu rumah tangga telah mengalami pergeseran menjadi usaha yang memiliki prospek yang sangat bagus. Kondisi ini didukung dengan pergeseran pola hidup yang menyukai kepraktisan termasuk dalam hal makanan. Terutama bagi orang yang sibuk bekerja tidak memiliki banyak waktu untuk mengolah dan menyiapkan makanan sendiri sehingga mereka mulai beralih dengan memanfaatkan jasa penyedia makan siap saji yang disebut juga pelayanan jasa boga.

Menurut Direktur Jenderal Perdagangan Dalam Negeri pada Kementerian Perdagangan RI, Srie Agustina menyatakan saat ini ada lebih dari 18.400 usaha kecil dan menengah yang terdata di Drektorat Jenderal Perdagangan Dalam Negeri pada Kemendag RI. Dari jumlah itu, 80 persennya merupakan unit usaha jasa boga yang terdiri usaha produk makanan olahan dan produk makanan siap saji seperti restoran, rumah makan dan warung makan. Usaha siap saji berjumlah 70 persen dari total usaha jasa boga, sedangkan sisanya usaha produk makanan 
olahan (http://www.pikiranrakyat.com/node/307909)10/12/2014-13:36). Berdasarkan data APJI (Asosiasi Pengusaha Jasa Boga Indonesia) sejak didirikan pada 1987 silam, hingga kini APJI telah beranggotakan sekitar 30.000 pengusaha yang terdiri atas pengusaha catering. Adapun di Kota Bandung salah satu usaha yang bergerak di bidang usaha jasa boga adalah katering. Katering dapat diklasifikasikan menjadi beberapa kategori seperti: katering pesta, katering industri/pabrik, katering perkantoran/bank, katering pelatihan atau diklat, dan katering rumah sakit. Menurut APJI (Asosiasi Pengusaha Jasa Boga Indonesia) usaha katering yang berkembangan di Kota Bandung banyaknya termasuk kedalam klasifikasi katering pesta yang mencapai 60 katering atau sekitar $66 \%$ dari 152 jumlah anggota APJI restoran, kafe dan penyedia jasa boga lainnya (http://life.viva.co.id/news/read/...//rabu, 10/12/2014-15-43 WIB). Jawa Barat merupakan daerah yang mempunyai industri kuliner yang sangat besar itu terbukti berdasarka hasil sensus ekonomi 2006 mengenai perusahaan makan dan minuman menurut klasifikasi usaha dan provinsi berjumlah 836 usaha.

Salah satu usaha yang bergerak di bidang usaha jasa boga adalah Celdi Katering. Celdi Katering merupakan salah satu klasifikasi katering pesta dan merangkat sebagai katering harian. Berdasarkan hasil wawancara dengan pemilik (senin, 23/3/2015) terjadi penurunan jumlah profit perusahaan dari tahun 20122014. Berdasarkan hasil pra penelitian mengenai tingkat kepuasan konsumen terhadap kualitas produk hasilnya yang menyatakan sangat puas sebesar 5\%, puas sebesar $30 \%$, cukup puas sebesar 50\%, dan yang menyatakan kurang puas sebesar $13 \%$. Dengan banyaknya konsumen yang sedikit merasa puas maka harus ditinjau kembali bahwa kualitas produk tidak memuaskan pelanggan. Hal ini harus diperhatikan oleh perusahaan karena dampaknya akan mempengaruhi keberhasilan perusahaan. Terutama dalam hal diperpanjangan atau tidaknya katering harian, juga minat dari konsumen untuk menggunakan jasa katering dan akhirnya akan berimbas terhadap pendapatan yang diterima oleh perusahaan untuk lebih jelasnya hasil penilaian responden mengenai tingkat kepuasan konsumen terhadap kualitas produk.

Berdasarkan hasil wawancara dengan pemilik katering (senin,23/3/2015) ditemukanya beberapa keluhan dari konsumen mengenai kualitas produk yaitu dari segi variasi makan yang dihidangkan terkadang tidak sesuai dengan menu yang lain, tingkat kematangan pada daging seperti daging untuk soto yang masih ada bercak darah, kebersihan dalam pencucian bahan makanan harus lebih teliti terutama saat membersihkan sayuran dan kesesuaian dan keteraturan rasa yang terkadang sering berubah-ubah.

Berdasarkan fenomena yang terjadi di atas, maka Celdi Katering melakukan perbaikan kualitas produk. Pengertian kualitas produk menurut Kotler dan Armstrong (2012:230) "Product quality the characteristic of a product or service that bear on its ability to satisfy stated or implied costomer needs". Kualitas produk adalah karakteristik produk atau jasa yang bergantung pada kemampuannya untuk memuaskan kebutuhan pelanggan yang dinyatakan atau diimplikasikan". Kemudian pengertian kualitas menurut American Society for Quality Control yang dikutif dari Kotler dan Keller (2013: 153)"Quality is the totality of features and characteristic of a product or service that bear on its 
ability to satisfy stated or implied needs". Maksudnya adalah ketika sudah bisa memenuhi atau melebihi ekspektasi para pelanggan, misi produk dan jasa tersebut sudah bisa dikatakan berhasil. Ketika produk sudah baik, maka akan muncul kepuasan konsumen dan keuntungan pun akan banyak di dapat pihak perusahaan yaitu terbentuknya pemasaran dari konsumen, sehingga konsumen tidak akan segan untuk menggunakan kembali produk perusahaan tersebut (loyal atau penggunaan ulang) ketika mereka memerlukanya.

Hal ini sesuai dengan pendapat yang diungkapkan oleh Kotler dan Keller (2013:150) "satisfaction is a person's feelings of pleasure or disappointment that result from comparing a product's perceived performance (or outcome) to expectation". Dengan kata lain konsumen akan merasa puas ketika mereka mendapatkan produk dan pelayanan sesuai dengan ekspektasi mereka dan sebaliknya konsumen akan merasa tidak puas dengan produk dan pelayanan yang mereka terima apabila tidak sesuai dengan apa yang mereka harapkan. Bahkan akan lebih baik jika kualiats produk dan pelayanan yang diberikan bisa melebihi ekspektasi para konsumen, karena hal itu akan membuat mereka merasa puas. Hal tersebut sesuai dengan yang diungkapkan oleh Hermawan (2011:11) “jika produk yang dikonsumsi berkualitas maka konsumen akan merasa puas terhadap produk tersebut".

Adapun upaya untuk meningkatkan kualitas produk, pemilik perusahaan melakukan hal-hal berikut: (1) untuk variasi makanan agar di sesuaikan dengan menu yang lain seperti dari segi metode memasak mulai dari pengolahan makanan yang di goreng, kukus, bakar dan lain-lain, dan memperhatikan kombinasi warna makanan, (2) mengatur tingkat kematangan makanan dengan memperhitungkan waktu pengolahan daging agar kematangan sesuai dengan yang diinginkan, (3) lebih memperhatikan kelezatan masakan dari segi rasa dengan membuat standar resep yang baku, dimana jumlah penggunaan bahan baku dan bumbu seimbang, dan (4) memberikan pelatihan pada karyawan yang bekerja di dapur agar menambah wawasan mengenai pengolahan makanan. Oleh karena itu dengan perbaikan kualitas produk yang dilakukan oleh Celdi Katering diharapkan dapat meningkatkan kepuasan konsumen dan meningkatkan jumlah pesanan.

Tujuan melakukan penelitian ini adalah sebagai berikut:

1. Untuk memperoleh gambaran kualitas produk pada Celdi Katering.

2. Untuk memperoleh gambaran kepuasan konsumen pada Celdi Katering.

3. Untuk mengetahui sejauh mana kualitas produk mempengaruhi tingkat kepuasan konsumen pada Celdi Katering.

\section{Pariwisata}

Menurut arti katanya, pariwisata berasal dari bahasa sansakerta yang terdiri dari dua kata, yaitu kata pari dan wisata. Kata pari berarti penuh, seluruh, atau semua. Kata wisata berarti perjalanan (Utama dan Mahadewi, 2012:107). Adapun menurut Alma, Buchari (2011:342), mengemukakan bahwa industri pariwisata adalah kumpulan macam-macam perusahan yang secara bersama menghasilkan barang-barang dan jasa (goods dan service) yang dibutuhkan para 
wisatawan pada khususnya dan traveller pada umumnya, selama dalam perjalanan. Kumpulan macam-macam hotel dan akomodasi lainnya, catering, trading bar dan restoran, tour operator, dan lainnya. Seddangkan menurut Ismayanti (2010:19) "industri pariwisata adalah kumpulan usaha pariwisata yang saling terkait dalam menghasilkan barang dan atau jasa bagi pemenuhan kebutuhan wisatawan pada penyelenggaraan pariwisata".

Usaha sarana pariwisata merupakan salah satu aspek penting dalam sistem dasar pariwisata berkaitan dengan fasilitas atau sarana pariwisata. Menurut Ismayanti (2010:122) yang termasuk sarana pariwisata diantaranya: trasfortasi, akomodasi, fasilitas makan dan minum, usaha wisata tirta dan kawasan pariwsata.

Jasa boga adalah usaha yang menyediakan jasa pelayan makan dan minum yang dikelola atas dasar pesanan yang dihidangkan tidak di tempat pengolahan (Ismayanti, 2010:122). Sedangkan menurut Fadiati (2011:1) "usaha jasa boga berasal dari kata to cater, yang terjemahan bebasnya berarti menyiapkan dan menyajikan makanan dan minuman untuk umum". Menurut Kardigantara (2006: 4-5) produk katering yaitu makanan merupakan tolak ukur kepuasan konsumen yang disesuaikan dengan kebiasaan dan pengalaman dari konsumen tersebut yang menikmati produk tersebut.

\section{Manajemen Pemasaran}

Menurut Kotler dan Keller (2012:5) manajemen pemasaran adalah sebagai berikut: "Marketing manajement as the art and science of choosing target markets and getting, keeping, and growing customers through creating, delivering, and communicating superior costomer value". Dalam pemasaran dikenal tujuh elemen pemasaran atau yang biasa disebut dengan bauran pemasaran (marketing mix). Elemen ini dibedakan dalam dua jenis produk, yaitu produk barang dan produk jasa. Ratnasari dan Aksa (2011:37) menyatakan bahwa, marketing mix merupakan tools bagi marketer yang berupa program pemasaran yang mempertajam segmentasi, targeting, positioning agar sukses. Ada perbedaan mendasar antara marketing mix jasa dan marketing mix produk barang. Marketing mix produk barang mencakup 4P, yaitu product, price, place, dan promotion, sedangkan untuk jasa keempat tahap tersebut masih kurang perlu ditambah dengan tiga tahap lainya yaitu, people, process, dan customer service.

\section{Kualitas Produk (Product Quality)}

Kotler dan Armstrong (2012:230) Product quality "the characteristic of a product or service that bear on its ability to satisfy stated or implied costomer needs". Kualitas produk adalah karakteristik produk atau jasa yang bergantung pada kemampuanya untuk memuaskan kebutuhan pelanggan yang dinyatakan atau diimplikasikan. Dimensi produk makanan menurut Marsum (2005:159) menspesifikasikan dimensi produk menjadi tujuh dimensi, dimana fungsinya adalah untuk menilai mutu makanan. Dimensi-dimensi tersebut antara lain sebagai berikut: 
1) Flavor (rasa/bau); harus diperhatikan bahwa rasanya harus enak dan baunya pun harus sedap,

2) Consistency (kemantapan;ketetapan); mutu hidangan/menu yang disajikan harus dijaga supaya mantap atau tetap baik, baik mutu mutu, rasa maupun aromanya.

3) Texture/Form/Shape (susunan/bentuk/potongan); didalam menyajikan menu lengkap harus ada hidangan yang ringan (yaitu hidangan pembuka), ada hidangan yang agak berat (yaitu sop), dilanjutkan dengan hidangan yang paling berat (hidangan utama), dan kemudian disusul dengan hidangan ringan lagi, yakni dessert (atau hidangan penutup). Texture/susunan dapat pula diartikan sebagai upaya menyusun suatu hidangan yang lengkap yang memperhatikan adanya hidangan : - Yang dikunyah baru ditelan: hidangan pembuka

4) Nutritional Content (kandungan gizi); makannan yang disajikan tetap harus diperhatikan kandungan gizinya. Walaupun di dalam Food Service Industry yang bersifat komersial (yaitu didalam semua restoran) penyajian makanan yang diutamakan penampilnya, gizi dinomerduakan, namun tidak berarti bahwa dalam menyusun menu boleh mengabaikan soal gizi ini.

5) Visual Appeal (daya penarik lewat ketajaman mata); di dalam menyusun suatu hidangan perlu diperhatikan penampilnya. Hidangan harus diatur, disusun dengan rapi, seni dan baik agar benar-benar menarik sehingga menimbulkan selera makan bagi para tamu.

6) Aromatic Appeal (daya penarik lewat bau harum); di dalam menyusun suatu hidangan perlu juga diperhaikan aromanya. Makan yang disajikan harus sedap/harum aromanya sehingga lebih membangkitkan selera makan para tamu. Menurut penyelidikan ternyata bahwa daya penarik lewat mata lebih kuat daripada daya penarik lewat bau makanan itu.

7) Temperature (panas/suhu); artinya di dalam menyajikan makanan harus diperhatikan suhunya. Makanan panas harus disajikan dalam keadaan benarbenar panas, dengan piring yang panas. Untuk makanan dingin harus disajikan dalam keadaan dingin dengan piring atau tempat dingin pula.

\section{Kepuasan Konsumen (Consumer Satification)}

Kotrel dan Keller (2013:150) "satisfaction is a person's feelings of pleasure or disappointment that result from comparing a product's perceived performance (or outcome) to expectation." Menurut Abdul dan Tantri (2012:38), "kepuasan adalah tingkat perasaan seseorang setelah membandingkan kinerja produk (atau hasil) yang ia rasakan dengan harapan."

\section{Dimensi Kepuasan Konsumen}

Sebuah perusahaan dalam meningkatkan kepuasan pelanggannya, membutuhkan strategi-strategi untuk meningkatkan kepuasan pada pelanggannya. Strategi-strategi tersebut dikemukakan oleh Kotler dan Keller (2013:150) yang 
menyatakan bahwa terdapat dua elemen pemasaran yang dapat meningkatkan kepuasan pelangganya yaitu:

1. Expected Quality

Gambaran dari manfaat suatu produk yang akan digunakan pelanggan.

2. Perceived Quality

Keyakinan mengenai produk atau jasa yang dialami atau jumlah atribut produk atau jasa yang diterima.

\section{Pengaruh Kualitas Produk terhadap Kepuasan Konsumen}

Besar kecilnya kepuasan konsumen sangat dipengaruhi oleh nilai kualitas. Konsumen akan menbandingkan produk dan jasa yang mereka terima dengan yang mereka harapkan. Kotler dan Keller (2013:153) menyatakan "satisfaction will also depend on product and service quality". Sedangkan Abdullah dan Tantri (2012:43) "ada hubungan erat antara kualitas barang dan jasa dengan kepuasan pelanggan serta profitabilitas." Hal itu selaras dengan pendapat Kotler dan Keller (2013:153) "product and service quality, costomers satisfaction, and company propability are intimately conneted". Hermawan (2011:11) “jika produk yang dikonsumsi berkualitas maka konsumen akan merasa puas terhadap produk tersebut". Dengan demikian nilai kualitas suatu produk dan jasa akan mempengaruhi besar kecilnya suatu kepuasan dalam diri konsumen yang menerima.

\section{METODE PENELITIAN}

Objek yang dijadikan responden dalam penelitian ini adalah konsumen Celdi Katering. Penelitian ini menggunakan dua jenis penelitian, yaitu deskriptif dan verifikatif. Dalam penelitan ini akan diuji apakah kualitas produk berpengaruh terhadap kepuasan konsumen yang menggunakan jasa Celdi Katering.Adapun sumber data dalam peelitian ini yaitu primer (internet, majalah, katalog, Data celdi catering) dan sekunder (konsumen). Adapun dalam penelitian ini, yang menjadi pupulasi adalah seluruh konsumen yang telah menggunakan dan merasakan produk dari Celdi Katering pada tahun 2014, dengan jumlah 42 orang. Karena populasi kurang dari 100 maka peneliti menjadi semuanya menjadi sampel (senseus). Teknik analisis data yang digunakan yaitu regresi linier sederhana.

Hipotesis yang diuji dalam penelitian ini adalah mengenai ada atau tidak adanya pengaruh antara variabel yang diteliti, yaitu variabel yang diangkat antara variabel bebas tentang kualitas produk (X) terhadap variabel terikat yaitu kepuasan konsumen (Y). Sehingga hipotesis dalam penelitian ini sebagi berikut:

$\mathrm{H}_{0}=0$, tidak terdapat pengaruh yang signifikan dari kualitas produk terhadap kepuasan konsumen.

$\mathrm{H}_{\mathrm{a}} \neq 0$, terdapat pengaruh yang signifikan dari kualitas produk terhadap kepuasan konsumen.

Di mana, jika $F_{\text {hitung }}>F_{\text {tabel }}$ maka $\mathrm{H}_{\mathrm{o}}$ ditolak dan $\mathrm{H}_{\mathrm{a}}$ diterima. 


\section{HASIL PENELITIAN DAN PEMBAHASAN}

Tanggapan responden terhadap kualitas produk yang dirasakan (Preceived). Hasil pengolahan data, diperoleh skor dari dimensi variabel kualitas produk yang terdiri dari flavor (rasa/bau), porsi, penampilan, warna, temperature (panas/suhu), aromatic appel (daya penarik lewat bau harum), texture/form/shape (susunan/bentuk/potongan). Untuk mengetahui skor yang paling tinggi dan paling rendah dari sub dimensi tersebut, dilakukan rekapitulasi tanggapan-tanggapan responden, mengenai kualitas produk yang dirasakan konsumen Celdi Katering pada Tabel 1 sebagai berikut:

\section{Tabel 1 \\ Tanggapan Konsumen \\ Terhadap Kualitas Produk Yang Dirasakan (Perceived)}

\begin{tabular}{|c|c|c|c|c|}
\hline No & Dimensi & $\begin{array}{l}\text { Total } \\
\text { Skor }\end{array}$ & $\begin{array}{l}\text { Rata-Rata } \\
\text { Skor }\end{array}$ & $\begin{array}{l}\% \\
\text { Skor }\end{array}$ \\
\hline 1 & Penampilan & 269 & 134.5 & $15.51 \%$ \\
\hline 2 & Flavor (rasa/bau) & 252 & 126 & $14.53 \%$ \\
\hline 3 & Porsi & 249 & 124.5 & $14.36 \%$ \\
\hline 4 & Warna & 246 & 123 & $14.19 \%$ \\
\hline 5 & $\begin{array}{l}\text { Aromatic Appel (daya penarik } \\
\text { lewat bau harum) }\end{array}$ & 243 & 121.5 & $14.01 \%$ \\
\hline 6 & $\begin{array}{l}\text { Texture/Form/Shape } \\
\text { (susunan/bentuk/poto ngan) }\end{array}$ & 244 & 122 & $14.07 \%$ \\
\hline 7 & Temperature (panas/suhu) & 231 & 115.5 & $13.32 \%$ \\
\hline & Total & 1734 & 867 & 100 \\
\hline
\end{tabular}

Sumber: Hasil Pengolahan Data 2015

Berdasarkan Tabel 1 diperoleh rekapituliasi tanggapan responden terhadap kualitas produk yang dirasakan. Kualitas produk yang terdiri dari 7 dimensi memiliki skor yang berbeda tipis. Dimensi yang memiliki penilaian paling tinggi adalah penampilan dengan rata-rata skor 134.5 atau $15.51 \%$. Hal tersebut dikarenakan penataan dan kebersihan suatu masakan dapat menarik perhatian konsumen yang akan memakanya. Menurut West, Wood dan Harger, et.al (dalam Fiani, 2012:1). Ungkapan "look good enough to eat" bukanlah suatu ungkapan yang berlebihan. Makanan harus baik dilihat saat berada di piring, di mana hal tersebut adalah suatu faktor yang penting. Kesehatan dan kebersihan dari makanan yang disajikan adalah contoh penting yang akan mempengaruhi penampilan makanan baik atau tidak untuk dinikmati. Penilaian terendah terdapat pada dimensi temperature (panas/suhu) dengan rata-rata skor 115.5 atau $13.32 \%$. Hal ini dikarenakan kesesuaian suhu dalam penghidangan makanan sangat diutamakan agar menjaga makanan tersebut agar tetap hangat untuk makanan hangat dan dingin untuk makanan yang dingin sampai akhir acara berlangsung. 
Tanggapan Responden Terhadap Kualitas Produk yang Diharapkan (Expected). Dari pengolahan data, diperoleh skor dari dimensi variabel kualitas produk yang terdiri dari flavor (rasa/bau), porsi, penampilan, warna, temperature (panas/suhu), aromatic appel (daya penarik lewat bau harum) texture/form/shape (susunan/bentuk/potongan). Untuk mengetahui skor yang paling tinggi dan paling rendah dari sub dimensi tersebut, dilakukan rekapitulasi tanggapan-tanggapan responden, mengenai kualitas produk yang diharapkan konsumen Celdi Katering pada Tabel 2 sebagai berikut:

Tabel 2

Rekapitulasi Tanggapan Konsumen Terhadap Kualitas Produk yang Diharapkan (Expected)

\begin{tabular}{|l|l|l|l|l|}
\hline No & Dimensi & $\begin{array}{l}\text { Total } \\
\text { Skor }\end{array}$ & $\begin{array}{l}\text { Rata-rata } \\
\text { Skor }\end{array}$ & $\begin{array}{l}\% \\
\text { Skor }\end{array}$ \\
\hline 1 & Penampilan & 351 & 175.5 & $14.73 \%$ \\
\hline 2 & Porsi & 345 & 172.5 & $14.48 \%$ \\
\hline 3 & Flavor (rasa/bau) & 341 & 170.5 & $14.31 \%$ \\
\hline 4 & Warna penarik & 338 & 169 & $14.27 \%$ \\
\hline 5 & $\begin{array}{l}\text { Aromatic Appel (daya } \\
\text { lewat bau harum) }\end{array}$ & 337 & 168.5 & $14.14 \%$ \\
\hline 6 & $\begin{array}{l}\text { Temperature (panas/suhu) } \\
\text { Texture/Form/Shape } \\
\text { (susunan/bentuk/potongan) }\end{array}$ & 331 & 165.5 & $13.89 \%$ \\
\hline \multicolumn{1}{|c|}{ Total } & 2383 & 1191.5 & $100 \%$ \\
\hline
\end{tabular}

Sumber: Pengolahan Data 2015.

Berdasrkan Tabel 2 diperoleh rekapituliasi tanggapan responden terhadap kualitas produk yang diharapkan. Kualitas produk yang terdiri dari 7 dimensi memiliki skor yang berbeda tipis. Dimensi yang memiliki penilaian paling tinggi adalah penampilan dengan rata-rata skor 175.5 atau $14.34 \%$. Hal tersebut dikarenakan penataan dan kebersihan suatu masakan dapat menarik perhatian konsumen yang akan memakanya. Menurut West, Wood dan Harger, et all (dalam Fiani, 2012, hlm. 1) Ungkapan "look good enough to eat" bukanlah suatu ungkapan yang berlebihan. Makanan harus baik dilihat saat berada di piring, di mana hal tersebut adalah suatu faktor yang penting. Kesehatan dan kebersihan dari makanan yang disajikan adalah contoh penting yang akan mempengaruhi penampilan makanan baik atau tidak untuk dinikmati. Penilaian terendah terdapat pada dimensi texture/form/shape (susunan/bentuk/potongan) dengan rata-rata skor 165,5 atau $13.89 \%$.

Tanggapan Responden Terhadap Kepuasan Di Celdi Katering. Kepuasan diperoleh dari hasil perbandingan antara kualitas produk yang dirasakan dan kualitas produk yang diharapkan oleh konsumen Celdi Katering. Berdasarkan 
hasil pengolahan data dari angket yang telah disebarkan kepada 42 responden yang pernah memesan dan menikmati mengenai kualitas produk, berikut adalah keseluruhan tanggapan responden tentang harapan dan kinerja yang diterima.

Tabel 3

Taggapan Responden

Terhadap Kepuasan dari Kualitas Produk Celdi Katering

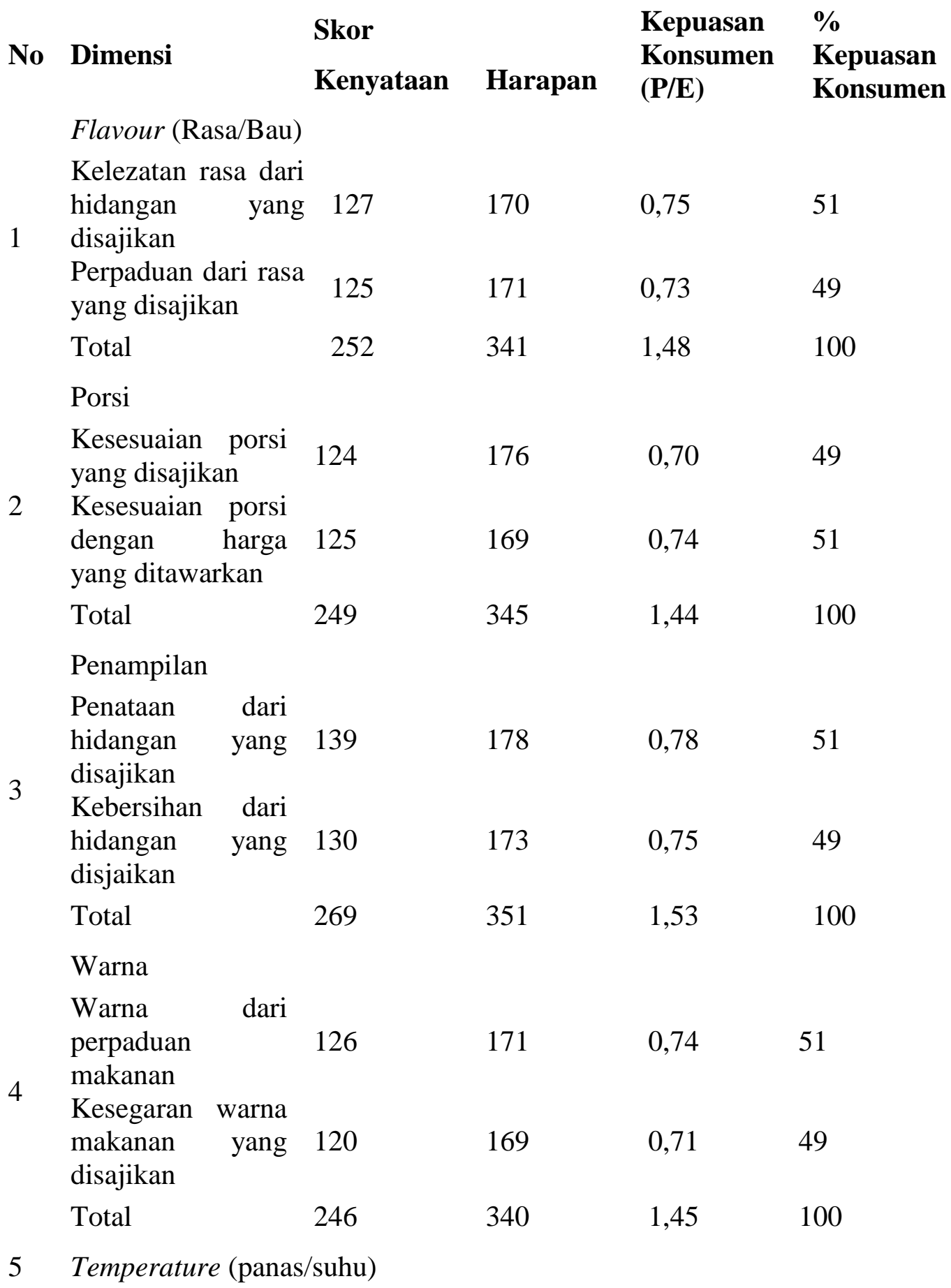




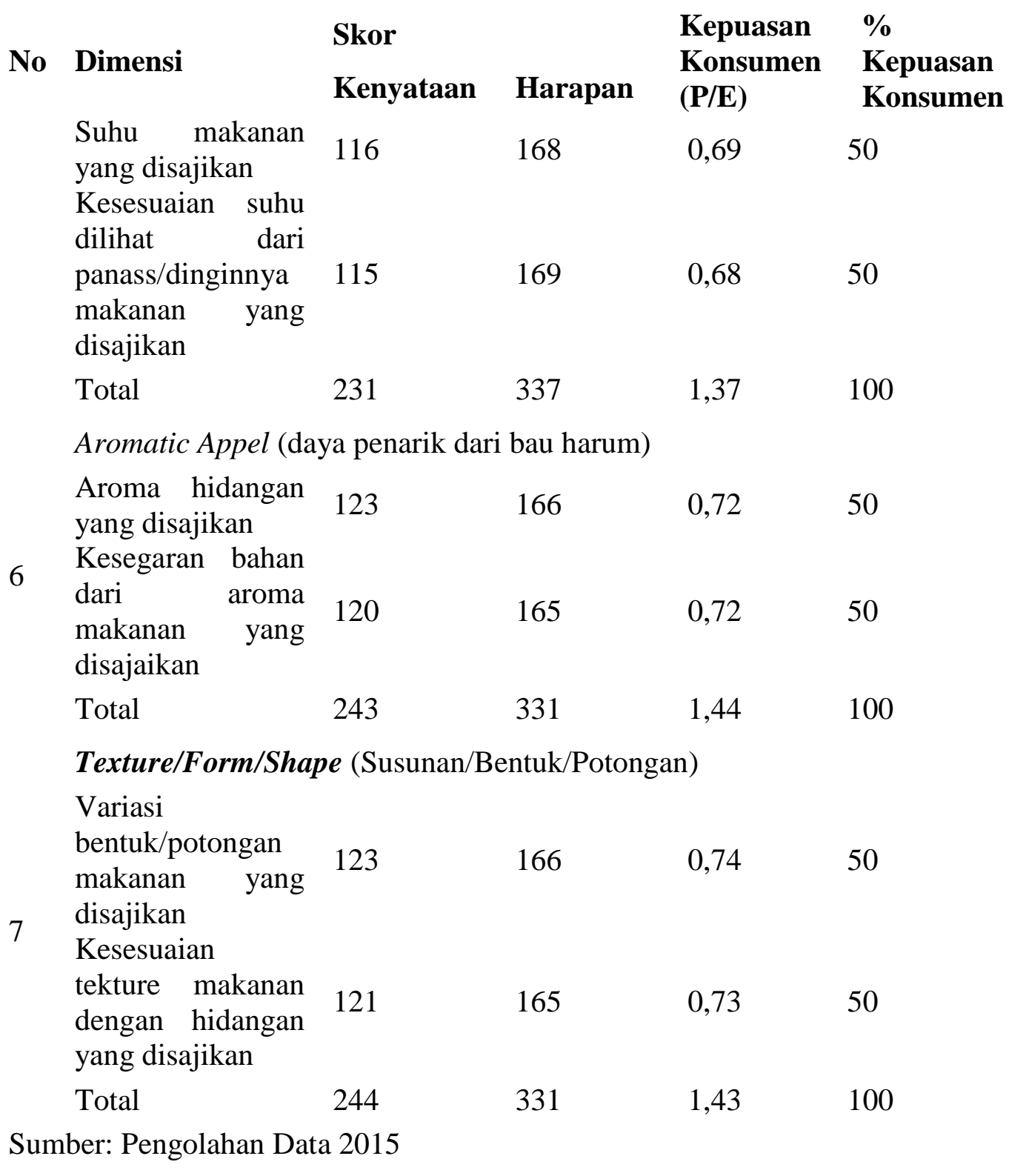

Berdasarkan Tabel di atas di peroleh tanggapan responden tentang harapan dan kinerja yang dirasakan terhadap dimensi kualitas produk. Berikut ini adalah Tabel rekapitulasi tentang tanggapan responden terhadap kepuasan konsumen yang dapat dilihat pada Tabel berikut: 
Tabel 4

Rekapitulasi Kepuasan Konsumen

Atas Kualitas Produk di Celdi Katering

\begin{tabular}{|c|c|c|c|c|c|}
\hline \multirow[b]{2}{*}{ No. } & \multirow[b]{2}{*}{ Dimensi } & \multicolumn{2}{|l|}{ Skor } & \multirow{2}{*}{$\begin{array}{l}\text { Tingkat } \\
\text { Kepuasan } \\
\text { Konsumen }\end{array}$} & \multirow{2}{*}{$\begin{array}{l}\text { Total } \\
\text { Kepuasan } \\
\text { Komsume } \\
\text { n }(\%)\end{array}$} \\
\hline & & Kenyataan & Harapan & & \\
\hline 1 & Flavor (rasa/bau) & 252 & 341 & 0.74 & $14.51 \%$ \\
\hline 2 & Porsi & 249 & 345 & 0.72 & $14.17 \%$ \\
\hline 3 & Penampilan & 269 & 351 & 0.77 & $15.05 \%$ \\
\hline 4 & Warna & 246 & 340 & 0.72 & $14.21 \%$ \\
\hline 5 & $\begin{array}{l}\text { Temperature } \\
\text { (panas/suhu) }\end{array}$ & 231 & 337 & 0.69 & $13.46 \%$ \\
\hline 6 & $\begin{array}{lrr}\text { Aromatic Appel (daya } \\
\text { penarik lewat bau } \\
\text { harum) }\end{array}$ & 243 & 338 & 0.72 & $14.12 \%$ \\
\hline 7 & $\begin{array}{l}\text { Texture/Form/Shape } \\
\text { (susunan/bentuk/poton } \\
\text { gan) }\end{array}$ & 244 & 331 & 0.74 & $14.48 \%$ \\
\hline & Total & 1734 & 2383 & 5.09 & $100 \%$ \\
\hline
\end{tabular}

Sumber: Hasil Pengolahan Data 2015

Berdasarkan hasil Tabel di atas, dapat diambil kesimpulan bahwa konsumen Celdi Katering secara keseluruhan tidak puas terhadap kualitas produk yang diberikan. Hal ini disebabkan karna nilai kinerja (kenyataan) yang dirasakan oleh konsumen Celdi Katering lebih rendah dibandingkan dengan nilai harapan (expected) konsumen. Adapun dari ke tujuh dimensi di atas, konsumen paling merasakan ketidak puasan terhadap pada temperature (panas/suhu). Sehingga dapat disimpulkan bahwa perlunya adanya peningkatan kualitas produk agar terciptanya kepuasan konsumen. Untuk mengetahui hubungan fungsional secara linear antara kedua varibel dilakukan pengujian regresi sederhana. Regresi juga digunakan untuk mengetahui seberapa besar pengaruh kualitas produk terhadap kepuasan konsumen. Berdasarkan hasil pengolahan data denganbantuan SPSS for windows, hasilnya sebagai berikut:

\section{Tabel 5}

\section{Coefficients $^{a}$}

\begin{tabular}{|c|c|c|c|c|c|}
\hline \multirow[t]{2}{*}{ Model } & \multicolumn{2}{|c|}{$\begin{array}{l}\text { Unstandardized } \\
\text { Coefficients }\end{array}$} & \multirow{2}{*}{$\begin{array}{l}\text { Standardized } \\
\text { Coefficients } \\
\text { Beta }\end{array}$} & \multirow[t]{2}{*}{$\mathrm{t}$} & \multirow[t]{2}{*}{ Sig. } \\
\hline & B & Std. Error & & & \\
\hline $\begin{array}{ll}1 & \text { (constanta) } \\
& \text { Kualitas Produk }\end{array}$ & $\begin{array}{l}3.624 \\
.189\end{array}$ & $\begin{array}{l}1.103 \\
.022\end{array}$ & .804 & $\begin{array}{l}3.285 \\
8.560\end{array}$ & $\begin{array}{l}.002 \\
.000\end{array}$ \\
\hline
\end{tabular}


a. Dependent Variabel : Kepuasan_Konsumen

Berdasarkan Tabel di atas mengenai koefisien regresi maka diperoleh persamaan regresi linear antara kualitas produk dan kepuasan konsumen yaitu sebagai berikut: $\mathrm{Y}=\mathrm{a}+\mathrm{bx}$ adalah kepuasan konsumen $(\mathrm{Y})=3,624+0,189 \mathrm{X}$. Artinya besar kepuasan konsumen (Y) yang terjadi mengikuti kualitas produk (X) sebesar 3,624.

Berdasarkan persamaan regresi di atas, kosntanta sebesar 3,624 menyatakan bahwa jika tidak ada kualitas produk $(\mathrm{X}=0)$ maka kepuasan konsumen 3,624 satu satuan nilai. Koefisien regresi 0,189 satu satuan nilai artinya setiap terjadi peningkatan kualitas produk akan meningkatkan kepuasan konsumen sebesar 0,189 satu satuan nilai dan sebaliknya jika terjadi penurunan kualitas produk akan menurunkan kepuasan konsumen sebesar 0,189 satu satuan nilai. Setelah itu dapat diketahui $t_{\text {hitung }}$ melalui uji $\mathrm{t}$ atau $\mathrm{t}_{\text {tabel }}$, penentuan $\mathrm{t}$ tabel dilakukan dengan tingkat signifikansi $5 \%$ atau 0,05 pada uji satu pihak dengan derajat kebebasan $(\mathrm{dk}) \mathrm{n}-2(\mathrm{dk})=42-2=40)$ maka didapat $\mathrm{t}_{\text {tabel }}$ sebesar 1,68385, karena $t_{\text {hitung }}>t_{\text {tabel}}$, yaitu 8,560 >1,68385 maka dapat disimpulkan Ho ditolak dan Ha diterima, artinya ada hubungan linear antara kualitas produk dengan kepuasan konsumen dengan tingkat signifikan sebesar 0,000 yang lebih kecil dari taraf signifikan 5\%. Karena probabilitas $(0,000)$ jauh lebih kecil drai 0,05 , maka model regresi bisa dipakai untuk memprediksi kepuasan konsumen atau dapat disimpulkan bahwa kualitas produk berpengaruh terhadap kepuasan konsumen.

Untuk mengetahui besarnya pengaruh variabel $\mathrm{X}$ terhadap $\mathrm{Y}$, maka digunakan koefisien determinasi sebagai berikut:

$$
\begin{aligned}
\mathrm{KD} & =r^{2} \times 100 \% \\
& =0,647 \times 100 \% \\
& =64,7 \%
\end{aligned}
$$

Berdasarkan perhitungan di atas, didapat hasil koefisien determinasi sebesar $64,7 \%$ dengan taraf signifikan 0,05, maka dengan kata lain terdapat pengaruh sebesar $64,7 \%$ antara kualitas produk dengan kepuasan konsumen, dan sisanya sebesar $35,3 \%$ dipengaruhi oleh variabel yang tidak diteliti dalam penelitian ini.

Pengujian hipotesis dilakukan dengan membandingkan nilai $\mathrm{F}$, jika $\mathrm{F}_{\text {hitung }}$ $>\mathrm{F}_{\text {tabel }}$ maka $\mathrm{H}_{0}$ ditolak dan $\mathrm{H}_{\mathrm{a}}$ diterima. $\mathrm{F}_{\text {tabel }}$ dengan derajat keabsahan 0,05 adalah sebesar 4,08. Dengan demikian $F_{\text {hitung }}(73,277)>F_{\text {tabel }}(4,08)$, maka kesimpulanya adalah $\mathrm{H}_{0}$ ditolak dan $\mathrm{H}_{\mathrm{a}}$ diterima, artinya terdapat pengaruh yang signifikan secara bersama-sama (simultan) dari kualitas produk terhadap kepuasan konsumen Celdi Katering. Berdasarkan nilai Sig. sebesar 0,000 yang lebih kecil dari 0,05 maka Ho ditolak dan Ha diterima, artinya kualitas produk memiliki pengaruh yang signifikan terhadap kepuasan konsumen di Celdi Katering.

\section{SIMPULAN}

Berdasarkan hasil penelitian dapat disimpulkan yaitu kualitas produk Celdi Katering cukup baik, hal tersebut telah dibuktikan melalui pengolahan data dari 
kualitas produk yang dirasakan. Adapun dari 7 dimensi yang dijelaskan, dimensi penampilan mempunyai nilai paling tinggi, sedangkan yang mempunyai nilai paling rendah adalah dimensi temperature (panas/suhu).

Konsumen Celdi Katering secara keseluruhan tidak puas terhadap kualitas produk yang telah diberikan. Hal tersebut disebabkan karena nilai kinerja (kenyataan) yang dirasakan oleh konsumen Celdi Katering lebih rendah dibandingkan dengan nilai harapan (expected) konsumen akan kualitas produk. Adapun dari tujuh dimensi yang dijelaskan, dimensi penampilan mempunyai nilai paling tinggi, sedangkan yang mempunyai nilai paling rendah adalah dimensi texture/form/shape.

Adapun kualitas produk berpengaruh terhadap kepuasan konsumen Celdi Katering sebesar 64,7\% sedangkan sisanya sebesar 33,3\% dipengaruhi oleh faktor lain seperti kualitas pelayanan, store atmosphere dan lain-lain.

\section{DAFTAR PUSTAKA}

Abdullah, Thamrin. Tantri, Francis. (2012). Manajemen Pemasaran. Jakarta: PT. Raja Grafindo Persada.

Alma, Buchari, (2011). Manajemen pemasaran \& pemasaran jasa. Bandung: Alfabeta.

Berita Resmi Statistik BPS No.03/01/Th.XVIII,2 Januari 2015 [online]. Tersedia: http://www.bps.go.id/website/brs_ind/brsInd-20150130161552.pdf)

Fadiati, Ari.(2011). Mengelola Usaha Jasa Boga Yang Sukses. Bandung: Pt.Remaja Rosdakarya

Handri, H. /"PRLM"/diugah tgl Senin, 9 Mar 2015/ 07:12:20 PM) [Online]. Tersedia: http://www.pikiran-rakyat.com/node/307909/ Rabu, 10/12/2014 $-13: 36$

Hermawan,Budi. (2011). Pengaruh Kualitas Produk terhadap Kepuasan, Reputasi Merek dan Loyalitas Konsumen Jamu Tolak Angin Pt.Sindo Muncul. Jurnal Manajemen Teori dan Terapan. Tahun 4, No. 2 Agustus 2011.

Irfan, L, \& Tasya, P. /Rabu, 10 Desember 2014 | 15:43 WIB/12 Mar 2015/17:08)

[Online]. Tersedia: (http://life.viva.co.id/news/read/567194-apjibertekadjadikan-kuliner-indonesia-tuan-rumah-di-negeri-sendiri/ (rabu,10/12/201415-43 WIB.

Ismayanti. (2010). Pengantar Pariwisata.Jakarta: Grasindo.

Kardigantara, S. (2006). Diktat:Operasional Katering. Bandung: STPB. 
Kotler, P., \& Armstrong, G. (2012).Principles of Marketing 14e.Pearson Education.

Kotler, P \& Keller, Lane, K. (2012). Marketing Management 13 e, Eangland: Horison edition. Pearsone Education. (2013). Marketing Management 14 e, Eangland: Horison edition. Pearsone Education.

Marsum, W. A.(2005).Restoran dan Segala Permasalahanya. Yogyakarta: Andi.

Ratnasari, T., Riri, \& H. Aksa, M. (2011). Manajemen Pemasaran Jasa. Bogor: Ghalia Indonesia.

Utama, Rai. Bagus, I Gusti dan Mahadewi,Eka,Ni Made. (2012). Metodologi Penelitian Pariwisata dan Perhotelan. Jakarta: Andi Publisher. 